\title{
PEMBENTUKAN KARAKTER MELALUI PENDIDIKAN ISLAM
}

\author{
Oleh: Dra. Ifham Choli M.Pd \\ ifhamholi@yahoo.co.id
}

\begin{abstract}
Islamic education is something that is very important in shaping one's character. Guidance and direction are religious teachings intended for humans to wholeheartedly believe in the existence of God, to be obedient and to obey to carry out God's commands in the form of worship and noble character. By studying Islamic religious education, it is hoped that someone can have good values in themselves, so that they can be translated into their daily behavior. In addition, Islamic religious education can also keep a person from doing something false. The application of Islamic education is done by increasing piety to God and noble character is a manifestation of the faith that is believed by everyone. Therefore, faith and piety that unite in a person will avoid acts that are destructive, slander, endanger the community and are very dangerous for the unity and integrity of the nation's future. Islamic education is very impotant in shaping and developing student character. Religious and moral education must integrate and interact through the social realities that develop in society. Education that includes religious values is ultimately able to shape a whole person.

Keyword: Character, Islamic, education
\end{abstract}

\section{ABSTRAK}

Pendidikan agama Islam merupakan sesuatu yang sangat penting dalam pembentukan karakter seseorang. Bimbingan dan arahannya adalah ajaran agama yang ditujukan agar manusia mempercayai dengan sepenuh hati akan adanya Tuhan, patuh dan tunduk melaksanakan perintah-Nya dalam bentuk beribadah, dan berakhlak mulia. Dengan mempelajari pendidikan agama Islam, diharapkan seseorang dapat memiliki nilai yang baik dalam diri, sehingga dapat ditranslasikan ke dalam tingkah laku perbuatannya sehari-hari. Selain itu pendidikan agama Islam juga dapat menjauhkan seseorang untuk melakukan hal yang bathil.

Penerapan Pendidikan Islam dilakukan dengan peningkatan taqwa kepada Tuhan Yang Maha Esa dan akhlak mulia adalah manifestasi dari keimanan yang diyakini setiap orang. Oleh karena itu keimanan dan ketaqwaan yang menyatu pada diri seseorang akan menghindarkan dari perbuatan-perbuatan yang bersifat merusak, fitnah, dan membahayakan masyarakat serta sangat berbahaya bagi persatuan dan kesatuan masa depan bangsa. 
Pendidikan Islam sangat penting dalam membentuk dan mengembangkan karakter siswa. Pendidikan agama dan moral harus saling berintegrasi dan berinteraksi melalui realitas sosial yang berkembang di masyarakat. Pendidikan yang memuat nilai-nilai keagamaan pada akhirnya mampu membentuk manusia seutuhnya.

Kata Kunci: Karakter, Pendidikan, Islam

\section{A. Pendahuluan}

Pendidikan menjadi salah satu faktor penting dalam membangun manusia kearah yang lebih baik, berkualitas, dan berkarakter. Pendidikan merupakan bagian integral dari pembangunan kehidupan bangsa dan negara, sebagaimana tercantum dalam UndangUndang Sistem Pendidikan Nasional Nomor 20 Tahun 2003 pasal 1, yang berbunyi: "Pendidikan adalah usaha sadar dan terencana untuk mewujudkan suasana belajar dan proses pembelajaran agar peserta didik secara aktif mengembangkan potensi dirinya untuk memiliki kekuatan spiritual keagamaan, pengendalian diri, kepribadian, kecerdasan, akhlak mulia, serta ketrampilan yang diperlukan dirinya, masyarakat, bangsa, dan negara".

Selanjutnya dalam penjelasan Pasal 37 ayat (1) dinyatakan bahwa pendidikan agama dimaksudkan untuk membentuk peserta didik menjadi manusia yang beriman dan bertakwa kepada Tuhan Yang Maha Esa serta berakhlak mulia. ${ }^{1}$

Pendidikan agama Isalam sangat penting dalam pengembangan karakter anak bangsa, sehingga Pendidikan agama harus diberikan pada semua jalur, jenjang, dan jenis pendidikan. Pendidikan agama Islam yang mendorong peserta didik untuk taat menjalankan ajaran agamanya dalam kehidupan sehari-hari dan menjadikan agama sebagai landasan etika dan moral dalam berbangsa dan bernegara.

Pendidikan agama pada hakekatnya merupakan bangunan bawah dari moral bangsa. Ketentraman hidup sehari-hari di dalam masyarakat tidak hanya semata-mata ditentukan oleh ketentuan hukum semata, tetapi juga dan terutama didasarkan atas ikatan moral nilai-nilai kesusilaan serta sopan santun yang didukung dan dihayati bersama oleh seluruh masyarakat. Terwujudnya kehidupan masyarakat yang berpegang pada moralitas tidak bisa lain kecuali dengan Pendidikan, khususnya pendidikan agama. Sebab moralitas yang mempunyai daya ikat dalam masyarakat bersumber dari agama, nilai-nilai agama dan norma-norma agama dalam bentuknya sebagai akhlak mulia. Agama yang berdimensi ke dalam pada kehidupan manusia membentuk daya tahan unuk menghadapi sikap dan tingkah laku yang tidak sesuai dengan ucapan batinnya.

Peranan agama demikian penting bagi tata kehidupan pribadi maupun masyarakat, maka dalam rangka pembangunan manusia Indonesia seutuhnya haruslah bertumpu di

\footnotetext{
${ }^{1}$ Abdul Rachman, 2005, Pendidikan Agama \& Pembangunan Watak Bangsa (Jakarta: RajaGrafindo Persada), hal.1
} 
atas landasan keagamaan yang kokoh. Jalan untuk mewujudkan tidak bisa lain kecuali hanyalah dengan menempatkan pendidikan agama sebagai faktor dasar yang paling penting.

Pendidikan yang dibutuhkan manusia, bukan hanya Pendidikan umum tetapi juga pendidikan agama Islam, karena pendidikan agama Islam merupakan pilar terpenting dalam membentuk manusia yang beriman dan bertaqwa kepada Allah SWT, sehat jasmani dan rohani. Tujuan Pendidikan bukan hanya meningkatkan intelektual siswa dengan berbagai ilmu pengetahuan, melainkan juga sikap mental atau karakter siswa, mendidik akhlak dan jiwa siswa, menanamkan rasa keutamaan, membiasakan dengan kesopanan, mempersiapkan kehidupan yang suci, ikhlas dan jujur. Dengan demikian tujuan pendidikan adalah mendidik budi pekerti dan Pendidikan jiwa.

Pendidikan karakter merupakan sebuah konsep yang ditanamkan kedalam diri seseorang dan dapat membentuk pribadi seseorang menjadi lebih santun, beradab, serta sehat jasmani dan rohani, sehingga akan mempunyai watak yang lebih baik dalam kehidupannya. Semakin maju suatu masyarakat maka akan semakin penting pula adanya Pendidikan bagi pertumbuhan dan perkembangan anak. Konsep Pendidikan tersebut merupakan harapan agar setiap individu memiliki kemampuan dalam mengelola dirinya, baik dalam lingkungan belajar, lingkungan keluarga, ataupun dalam lingkungan sosialnya.

\section{B. PEMBAHASAN}

\section{Pengertian Karakter}

Karakter adalah moralitas, kebenaran, kebaikan, kekuatan, dan sikap seseorang yang ditunjukkan kepada orang lain melalui tindakan. ${ }^{2}$ Baik atau buruknya karakter tergambar dalam moralitas yang dimiliki. Begitu pula dengan kebenaran yang merupakan perwujudan dari karakter. Suatu kebenaran tidak akan terbangun dengan sendirinya tanpa melibatkan kehadiran karakter yang menopang segala upaya untuk menegakkan suatu kebenaran.

Karakter dapat dimaknai sebagai nilai dasar yang membangun pribadi seseorang, terbentuk baik karena pengaruh hereditas maupun pengaruh lingkungan, yang membedakannya dengan orang lain, serta diwujudkan dalam sikap dan perilakunya dalam kehidupan sehari-hari. ${ }^{3}$

Sutarjo Adisusilo(2014) mengungkapkan bahwa karakter adalah seperangkat nilai yang telah menjadi kebiasaan hidup sehingga menjadi sifat tetap dalam diri seseorang,

\footnotetext{
2 Muhammad Yaumi, 2014, Pendidikan Karakter (Jakarta: Prenadamedia Group), hal. 7

${ }^{3}$ Muchlas Samani dan Hariyanto, 2016, Pendidikan Karakter (Bandung: PT Remaja Rosdakarya Offset), hal. 43
} 
misalnya kerja keras, pantang menyerah, jujur, sederhana, dan lain-lain. ${ }^{4}$ Dengan karakter inilah kualitas seoarang pribadi diukur.

Dari beberapa definisi di atas maka dapat disimpulkan bahwa yang dimaksud dengan karakter adaah watak sekaligus kepribadian atau perilaku yang tampak dalam kehidupan sehari-hari baik dalam bersikap maupun dalam bertindak.

Muhammad Yaumi, (2014) menguraikan sebelas prinsip dasar dalam menunjang keberhasilan pelaksanaan Pendidikan karakter, yaitu:

a) Komunitas sekolah mengembangkan nilai-nilai etika dan kemampuan inti sebagai landasan karakter yang baik.

b) Sekolah mendifinisikan karakter secara komprehensif untuk memasukkan pemikiran, perasaan, dan perbuatan.

c) Sekolah menggunakan pendekatan komprehensif, sengaja, dan proaktif untuk mengembangkan karakter.

d) Sekolah menciptakan masyarakat peduli karakter.

e) Sekolah memberikan kesempatan kepada peserta didik untuk melakukan tindakan moral.

f) Sekolah menawarkan kurikulum akademik yang berarti dan menantang yang menghargai semua peserta didik mengembangkan karakter, dan membantu mereka untuk mencapai keberhasilan.

g) Sekolah mengembangkan motivasi diri peserta didik.

h) Staf sekolah adalah masyarakat belajar etika yang membagi tanggung jawab untuk melaksanakan pendidikan karakter dan memasukkan nilai-nilai inti yang mengarahkan peserta didik.

i) Sekolah mengembangkan kepemimpinan bersama dan dukungan yang besar terhadap permulaan atau perbaikan pendidikan karakter.

j) Sekolah melibatkan anggota keluarga dan masyarakat sebagai mitra dalam upaya pembangunan karakter.

k) Sekolah secara teratur menilai dan mengukur budaya dan iklim, fungsi-fungsi staf sebagai pendidik karakter serta sejauh mana peserta didikk mampu memanifestasikan karakter yang baik dalam pergaulan sehari-hari.

\section{Pengertian Pendidikan Islam}

Pendidikan Islam adalah usaha sadar untuk membimbing manusia menjadi pribadi beriman yang kuat secara fisik, mental, dan spiritual, serta cerdas, berakhlak mulia, dan memiliki ketrampilan yang diperlukan bagi kebermanfaatan dirinya, masyarakatnya, dan lingkungannya. ${ }^{5}$

Menurut H.M Arifin (2014), Pendidikan Islam berarti sistem Pendidikan yang dapat memberikan kemampuan seseorang untuk memimpin kehidupannya sesuai dengan

\footnotetext{
${ }^{4}$ Sutarjo Adisusilo, 2014, Pembelajaran Nilai-Karakter (Jakrta: RajaGrafindo Persada), hal. 78

${ }^{5}$ Muhammad Hambal Shafwan, 2014, Intisari Sejarah Pendidikan Islam (Solo: Pustaka Arafah), hal. 19
} 
cita-cita dan nilai-nilai Islam yang telah menjiwai dan mewarnai corak kepribadiannya. Dengan kata lain manusia yang mendapatkan pendidikan Islam harus mampu hidup di dalam kedamaian dan kesejahteraan sebagaimana diharapkan oleh cita-cita Islam ${ }^{6}$

Pendapat lain mengatakan bahwa Pendidikan Islam adalah usaha mengubah tingkah laku individu dalam kehidupan pribadinya atau kehidupan kemasyarakatannya dan kehidupan dalam alam sekitarnya melalui proses pendidikan. ${ }^{7}$

Dari beberapa definisi di atas, maka Pendidikan Islam adalah suatu usaha untuk mengarahkan manusia menjadi bermanfaat, beradab, dan bermartabat dalam menjalankan kehidupan sesuai dengan ajaran Islam, serta menghasilkan output yang berkarakter baik.

\section{Kedudukan Pendidikan Islam}

Agama Islam merupakan agama yang paling sempurna dan sesuai dengan fitrah manusia dengan segala dimensi kemanusiaannya. Ajaran Islam yang termuat dalam kitab Al-Qur'an, yang diturunkan oleh Allah Swt. untuk mengatur seluruh aspek kehidupan manusia, sebagai petunjuk bagi manusia dalam mencapai kehidupan yang Bahagia dan sejahtera baik di dunia dan di akherat. Demikian kedudukan agama Islam dalam kehidupan manusia, maka ajaran agama Islam merupakan ajaran dasar yang menjadi pedoman hidup manusia dalam segala aspek hidup dan kehidupannya. ${ }^{8}$

Dalam Undang-Undang Nomor 20 Tahun 2003 menyebutkan bahwa Pendidikan adalah usaha sadar dan terencana untuk mewujudkan suasana belajar dan proses pembelajaran agar peserta didik secara aktif mengembangkan potensi dirinya untuk memiliki kekuatan spiritual keagamaan, pengendalian diri, kepribadian, kecerdasan, akhlak mulia, serta ketrampilan yang diperlukan dirinya, masyarakat, bangsa, dan negara.

Kedudukan pendidikan agama Islam sebagai mata pelajaran yang diajarkan di sekolah adalah upaya menyampaikan ilmu pengetahuan agama Islam tidak hanya untuk dipahami dan dihayati, tetapi juga diamalkan dalam kehidupan sehari-hari, misalnya kemampuan siswa dalam melaksanakan wudhu, shalat, puasa, dan ibadah-ibadah lain yang sifatnya hubungan dengan Allah, dan juga kemampuan siswa dalam beribadah yang sifatnya hubungan antara sesame manusia, misalnya siswa bisa melakukan zakat, sadaqah, jual beli dan lain-lain yang termasuk ibadah dalam arti luas.

Pendidikan agama Islam yang diajarkan tidak cukup hanya diketahui dan diresapi saja, tetapi dituntut pula untuk diamalkan. Bahkan ada sebagian materi yang wajib untuk dilaksanakannya, seperti shalat, puasa, zakat, dan lain-lain. Hal ini yang membedakan dengan pelajaran lain.

Pendidikan agama Islam yang kedudukannya sebagai mata pelajaran wajib diikuti seluruh siswa yang beragama Islam pada semua satuan jenis, dan jenjang sekolah. hal ini

\footnotetext{
${ }^{6}$ HM Arifin, 2014, Ilmu Pendidikan Islam (Jakarta: Bumi Aksara), hal. 7

${ }^{7}$ Haidar Putra Daulay, 2014, Pendidikan Islam dalam Perspektif Filsafat (Jakarta: Kencana), hal. 13

8 Tim Dosen Pendidikan Agama Islam, 2016, Pendidikan Agama Islam Berbasis Karakter Di perguruan

Tinggi, (Jakarta: RajaGrafindo Persada), hal40
} 
sesuai dengan UUD 1945 yang menjamin warga negara untuk beribadah menurut agamanya masing-masing. Pendidikan agama Islam merupakan usaha sadar untuk menyiapkan peserta didik meyakini, memahami, menghayati, dan mengamalkan agama Islam melalui kegiatan bimbingan, pengajaran dan atau latihan untuk mewujudkan pribadi Muslim yang beriman, bertakwa kepada Allah Swt, dan berakhlak mulia. Sementara itu, dalam kehidupan pribadi, bermasyarakat, berbangsa, dan bernegara serta memiliki bekat untuk melanjutkan pendidikan yang lebih tinggi. ${ }^{9}$

Pendidikan agama Islam sebagai satu bidang studi merupakan kesatuan yang tidak bisa dipisahkan dengan bidang studi lainnya, karena bidang studi secara keseluruhan berfungsi tercapainya tujuan umum pendidikan nasional. Oleh karena itu antara, satu bidang studi dengan bidang studi lainnya hendaknya saling membantu dan saling kuat menguatkan. Misalnya dalam pelajaran Ilmu Pengetahuan Alam (IPA) diajarkan bagaimana sifat-sifat dan bagaimana keadaan suatu benda serta kegunaannya bagi manusia, maka hendaknya dikemukakan sedikit bahwa benda tersebut adalah nikmat Allah Swt untuk manusia.

\section{Peran dan Fungsi Pendidikan Agama Islam}

Pendidikan agama Islam di sekolah berperan sebagai pendukung tujuan umum pendidikan nasional, yang tidak lain bahwa tujuan umum pendidikan nasional adalah untuk membentuk peserta didik menjadi manusia yang beriman dan bertakwa kepada Tuhan Yang Maha Esa serta berakhlak mulia. Fungsi pendidikan nasional yang juga merupakan tujuan pendidikan agama Islam, maka pendidikan agama Islam berperan sebagai berikut :

a. Membentuk watak atau karakter serta peradaban bangsa dalam rangka membangun manusia seutuhnya dan masyarakat Indonesia seluruhnya, maka Pendidikan agama Islam berfungsi sebagai berikut :

1) Dalam aspek individu adalah untuk membentuk manusia yang beriman bertakwa terhadap Tuhan Yang Maha Esa dan berakhlak mulia.

2) Dalam aspek kehidupan bermasyarakat dan bernegara adalah untuk:

a. Melestarikan Pancasila dan melaksanakan UUD 1945.

b. Melestarikan asas pembangunan nasional, yakni perikehidupan dalam keseimbangan.

c. Melestarikan modal dasar pembangunan nasional, yakni modal rohaniyah dan mental berupa peningkatan iman, takwa terhadap Tuhan Yang Maha Esa dan akhlak mulia.

d. Membimbing warga negara Indonesia menjadi warga negara yang baik sekaligus umat yang menjalankan ibadah.

b. Menjadi manusia yang beriman dan bertakwa, maksudnya adalah manusia yang selalu taat dan tunduk terhadap apa-apa yang diperintahkan oleh Allah Swt dan

\footnotetext{
${ }_{9}^{9}$ Abdul Rachman Shaleh, 2005, Pendidikan Agama \& Pembangunan Watak Bangsa, (Jakarta: Raja Grafindo Persada), hal. 39
} 
menjauhi segala larangan-Nya. Manusia yang beriman adalah manusia yang mampu mengembangkan sikap dan untuk memiliki perilaku seirama dan mendekati sifat-sifat Allah, mengukuti petunjuk Allah serta menerima bisikan hati serta petunjuk yang baik. ${ }^{10}$

\section{Kerangka Dasar Pendidikan Agama Islam}

Sumber agama Islam yaitu al-Qur'an dan al-Hadits. Kedua sumber tersebut memuat komponen agama Islam, komponen tersebut menjadi isi kerangka dasar agama Islam. Adapun kerangka dasar agama Islam terdiri atas akidah, syari'ah dan akhlak. $^{11}$

\section{a. Akidah}

Akidah secara etimologi adalah ikatan, sangkutan. Menurut terminology makna akidah adalah iman, keyakinan. Karena itu akidah selalu ditautkan dengan rukun iman yang merupakan asas seluruh ajaran Islam. Pembahasan tentang akidah dilakukan oleh ilmu kalam, yakni ilmu hasil penalaran atau ijtihad manusia yang membahas dan menjelaskan tentang kalam Ilahi (mengenai akidah) atau juga disebut ilmu tauhid karena membahas dan menjelaskan (terutama) tentang KeEsaan Allah (tauhid), atau meminjam istilah asing, kini sering dipergunakan istilah teologi yakni ilmu tentang ketuhanan.

Akidah adalah ikatan dan perjanjian yang kokoh. Manusia dalam hidup ini terpola ke dalam ikatan dan perjanjian baik dengan Allah SWT, dengan sesama manusia maupun dengan alam lainnya. Jika seseorang terikat dengan kekafiran disebut akidah kafir, jika terikat dengan kemusyrikan disebut akidah musyrik, jika terikat dengan keislaman disebut akidah Islam, dan seterusnya. ${ }^{12}$

Ruang lingkup kajian akidah berkaitan erat dengan rukun iman. Rukun iman tersimpul kokoh dalam hati bersifat mengikat dan mengandung perjanjian dengan Allah Ta'ala sebagai rukun pertama.

Unsur-unsur keimanan (akidah) yang ditanamkan kepada peserta didik merupakan landasan bagi pembentukan keberagamaan mereka, yang fungsinya juga bermuara pada pembentukan pribadi peserta didik. Keyakinan yang tertanam pada diri seseorang tentang adanya Tuhan, Zat yang bersifat Omnipotent (serba maha), Mahapencipta, Mahamengetahui, Mahapengasih dan seterusnya, akan melahirkan kesadaran bahwa ada kekuasaan di atas segala kekuasaan di muka bumi, dan yang menempatkan manusia sebagai makhluk yang tidak bisa memosisikan diri dan berbuat melewati kekuasaan dan keberadaan Allah Sang Pencipta. Kesadaran tersebut diantaranya akan menghindarkan manusia dari sifat mengagungkan diri sendiri dan berlaku sombong atau merendahkan orang lain. Penanaman keyakinan akan unsur keimanan lainnya akan berfungsi sama untuk

\footnotetext{
10 Ibid. Hal. 40

${ }^{11}$ Mohammad Daud Ali, 2016, Pendidikan Agama Islam (Jakarta: RajaGrafindo Persada), hal. 133

12 Deden Makbuloh, 2015, Pendidikan Agama Islam, (Jakarta: RajaGrafindo Persada), hal. 85
} 
mendorong tumbuhnya kesadaran yang pada gilirannya akan menuntun lahirnya perilaku bertanggung jawab sebagai makhluk Tuhan.

Akidah yang benar yaitu akidah yang dapat dipahami oleh akal sehat dan diterima oleh hati karena sesuai dengan fitrah manusia. Alat ukur akidah seseorang adalah hati, yang paling tepat mengukur hati adalah dirinya sendiri. Oleh karena itu mengukur akidah seseorang hanya akan akurat manakala dievaluasi oleh pemilik hati itu sendiri.

Agar tidak salah dalam menilai akidah sendiri, perlu melihat pada petunjuk-petunjuk yang diberikan oleh Allah Swt. dalam Al-Qur'an ditambah dengan petunjuk-petunjuk Rasul dalam al-Hadis. Setelah itu perlu melihat penjelasan ulama yang otoritatif. Dalam hal ini potensi akal sehat sangat diperlukan. Allah Swt mendorong manusia untuk berpikir mengoptimalkan akalnya.

b. Syari'ah

Syari'ah menurut etimologi adalah jalan (ke sumber atau mata air) yang harus ditempuh (oleh setiap umat Islam). Menurut peristilahan, syari'ah (t) ialah sistem norma (kaidah) Ilahi yang mengatur hubungan manusia dengan Allah, hubungan manusia dengan sesama manusia dalam kehidupan sosial, hubungan manusia dengan benda dan alam lingkungan hidupnya. Kaidah yang mengatur hubungan langsung manusia dengan Allah disebut kaidah ibadah atau kaidah ubudiyah yang disebut juga kaidah ibadah murni (mahdah), kaidah yang mengatur hubungan manusia selain dengan Allah (dengan sesama manusia, dan dengan alam lingkungan hidup) disebut kaidah muamalah (t). Disiplin ilmu yang khusus membahas dan menjelaskan syari'ah disebut ilmu fikih.

Syariah adalah hukum-hukum yang ditetapkan Allah Ta'ala untuk mengatur manusia baik dalam hubungannya dengan Allah Swt, dengan sesama manusia, dengan alam semesta, dan dengan makhluk ciptaan lainnya. Syariah ini ditetapkan oleh Allah untuk kaum muslimin, baik yang dimuat dalam Al-Qur'an maupun dalam Sunnah Rasul. ${ }^{13}$

Allah adalah pembuat hukum yang tertinggi. Syariah Islam adalah penjelmaan konkret kehendak Allah di tengah manusia hidup bermasyarakat. Syariah merupakan prinsip yang tercantum dalam Al-Qur'an dan prinsip AlQur'an itu sendiri. Agar prinsip tersebut dapat diwujudkan dengan baik, tentu memerlukan contoh. Dalam hal ini dibutuhkan contoh-contoh dari Nabi. Melalui perilaku dan ucapan Nabi tersebut, manusia dapat memahami apa yang menjadi kehendak Allah Ta'ala itu. Oleh karena itu Nabi dan Rasul patut dicontoh dalam melaksanakan syari'ah.

Para ahli fikih menjelaskan Syariah untuk menunjukkan nama hukum yang ditetapkan oleh Allah untuk para hamba-Nya dengan perantaraan Rasul-

${ }^{13}$ Ibid. hal.122 
Nya, supaya para hamba-Nya itu melaksanakannya dengan dasar iman., baik hukum itu mengenai hukum formal maupun hukum etika (akhlak).

Syari'ah yang diwujudkan dengan pengamalan ibadah adalah merupakan aktualisasi dari keimanan. Meskipun pengamalan ibadah pada prinsipnya merupakan wujud dari kepatuhan dan pengabdian manusia sebagai hamba Tuhan, tetapi ibadah juga berfungsi sebagai penanaman nilai-nilai, seperti menumbuhkan disiplin, tanggung jawab, hidup bersih lahir dan batin, kebersamaan dan persaudaraan, dan nilai-nilai lainnya. Di samping itu ibadah sosial memiliki dimensi pengmalan nilai sosial yang memberi inspirasi bagi terciptanya perilaku dan interaksi antara sesama atas dasar penghargaan pada kemanusiaan itu sendiri.

Syariah yang mengatur hubungan manusia dengan Allah disebut dengan 'ibadah, sedangkan yang mengatur hubungan manusia dengan manusia atau alam lainnya disebut muamalah. Semua itu adalah hukum-hukum Allah Ta'ala untuk keselamatan hidup manusia. Syari'ah Islam yang mengatur kehidupan manusia di dunia dalam rangka mencapai kebahagiaannya di dunia dan akhirat.

\section{c. Akhlak}

Akhlak ialah sikap yang menimbulkan kelakuan baik atau buruk. Berasal dari kata khuluk yang berarti perangai, sikap, perilaku, watak, budi pekerti. Perkataan itu mempunyai hubungan dengan sikap, perilaku, atau budi pekerti manusia terhadap Khalik (Pencipta alam semesta) dan makhluk (yang diciptakan). Karena itu dalam garis besarnya akhlak berkenaan dengan sikap dan perbuatan manusia terhadap (a) Khalik, yakni Tuhan Maha Pencipta, dan (b) terhadap sesama makhluk (segala yang diciptakan oleh Khalik itu). Sikap terhadap sesama makhluk dapat dibagi dua yaitu:

(1) Akhlak terhadap sesama manusia yakni diri sendiri, keluarga, tetangga dan masyarakat.

(2) Akhlak terhadap makhluk bukan manusia yang ada disekitar lingkungan hidup kita.

Unsur akhlak dengan sendirinya mengandung prinsip-prinsip moral dan kaidah perilaku dalam hubungan antara sesama manusia. Dengan begitu pendidikan akhlak tidak selesai pada tingkat pewarisan pengetahuan tentang kaidah dan prinsip moral yang mengatur perilaku, tetapi lebih jauh dari itu bagaimana kaidah dan aturan moral yang mengatur perilaku tersebut betul-betul terwujud di dalam perilaku nyata sehari-hari.

Manusia beriman, bertakwa, dan berakhlak mulia terbentuk melalui proses kehidupan dan terutama melalui proses pendidikan, khususnya kehidupan beragama dan pendidikan agama. Proses pendidikan itu terjadi dan berlangsung seumur hidup manusia, baik di lingkungan keluarga, sekolah, dan di masyarakat.

Akhlak Islam dapat dikatakan sebagai akhlak yang islami adalah akhlak yang bersumber pada ajaran Allah dan Rasul-Nya. Akhlak islami ini merupakan 
amal perbuatan yang sifatnya terbuka sehingga dapat menjadi indicator seseorang apakah seorang Muslim yang baik atau buruk. Akhlak ini merupakan buah dari akidah dan syari'ah yang benar. Secara mendasar, akhlak ini erat kaitannya dengan kejadian manusia yaitu Khalik (pencipta) dan makhluk (yang diciptakan). Rasulullah diutus untuk menyempurnakan akhlak yaitu untuk memperbaiki hubungan makhluk (manusia) dengan Khalik (Allah Ta'ala) dan hubungan baik antara makhluk dengan makhluk.

Di dalam Islam untuk menguji akhlak itu baik atau buruk ukuran atau rujukannya adalah Al-Qur'an dan As-Sunnah. Perbuatan apa saja yang diperintahkan dan dianjurkan dalam Al-Qur'an dan As-Sunnah adalah merupakan akhlak yang baik. Perbuatan apa saja yang dilarang dalam Al-Qur'an dan AsSunnah adalah termasuk akhlak yang tidak baik. ${ }^{14}$

Proses belajar mengajar yang diharapkan di dalam pendidikan akhlak adalah lebih kepada mendidik bukan mengajar.

Adapun indikator akhlak yang bersumber dari Al-Qur'an yaitu:

1) Kebaikannya bersifat mutlak (al-khairiyyah al-muthlak), yaitu kebaikan yang terkandung dalam akhlak merupakan kebaikan murni dalam lingkungan, keadaan, waktu, dan tempat apa saja.

2) Kebaikannya bersifat menyeluruh (as-shalahiyyah al-ammah), yaitu kebaikan yang terkandung di dalamnya kebaikan untuk seluruh umat manusia.

3) Implementasinya bersifat wajib (al-ilzam al-mustajab), yaitu merupakan hukum tingkah laku yang harus dilaksanakan sehingga ada sanksi hukum.

4) Pengawasan bersifat menyeluruh (ar-raqabah al-muhitah), yaitu melibatkan pengawasan Allah Swt. dan manusia lainnya, karena sumbernya dari Allah Swt. ${ }^{15}$

Akhlak mulia perlu diimplementasikan dalam hidup sehari-hari. Bentuk implementasinya bisa dalam ucapan-ucapan yang mulia atau dalam perbuatanperbuatan terpuji. Islam mengatur tata cara berakhlak mulia baik terhadap Allah, diri sendiri, keluarga, tetangga, dan lingkungan. Seseorang yang terbiasa melakukan hal-hal sesuai ajaran Islam akan memiliki karakter yang baik.

Pendidikan Islam merupakan salah satu materi yang bertujuan meningkatkan akhlak mulia serta nilai-nilai spiritual dalam diri anak. Hal ini menunjukkan bahwa pendidikan agama mempunyai peranan yang penting dalam pengembangan karakter di sekolah. Oleh karena itu Pendidikan Islam menjadi salah satu mata pelajaran wajib baik di sekolah tingkat dasar, menengah, dan perguruan tinggi. Maka sekolah harus mampu menyelenggarakan Pendidikan Islam secara optimal dengan cara mengaplikasikan nilai-nilai agama dalam

${ }^{14}$ Ibid . Hal. 139

${ }^{15}$ Op.cit, hal. 141 
lingkungan sekolah yang dilakukan oleh seluruh guru dan peserta didik secara bersama-sama serta berkesinambungan.

Akhlak merupakan suatu keadaan yang melekat dalam jiwa, maka perbuatan dikatakan akhlak jika perbuatan itu dilakukan berulang-ulang. Jika seseorang melakukan perbuatan tertentu hanya dilakukan sesekali saja, maka belum dapat disebut akhlak, tapi ini baru disebut perilaku saja. Apabila perilaku ini dilakukan berulang kali sehingga menjadi kebiasaan dalam dirinya baru disebut akhlak.

Adapun hal-hal yang perlu dibiasakan sebagai akhlak yang terpuji dalam Islam, antara lain:

1) Berani dalam kebaikan, berkata benar serta menciptakan manfaat, baik bagi diri maupun orang lain.

2) Adil dalam memutuskan hokum tanpa membedakan kedudukan, status sosial ekonomi, maupun kekerabatan.

3) Arif dan bijaksana dalam mengambil keputusan

4) Pemurah dan suka menafkahkan rizki baik ketika lapang maupun sempit

5) Ikhlas dalam beramal semata-mata demi meraih rida Allah

6) Cepat bertobat kepada Allah ketika berdosa

7) Jujur dan amanah

8) Tidak berkeluh kesah dalam menghadapi masalah hidup

9) Penuh kasih saying

10) Lapang hati dan tidak balas dendam

11) Menjaga diri dari perbuatan yang menghancurkan kehormatan dan kesucian diri

12) Malu melakukan perbuatan yang tidak baik

13) Rela berkurban untuk kepentingan umat dan dalam membela agama Allah. ${ }^{16}$

Hubungan akhlak, tauhid, dan syari'ah tidak bisa dipisahkan, masing-masing akan hilang maknanya jika yang satu dengan yang lain dipisahkan. Ketiganya merupakan satu kesatuan yang utuh. Tauhid yang baik akan membuahkan syari'ah yang baik, dan syari'ah yang baik akan membuahkan akhlak yang baik pula. Demikian pula akhlak yang baik karena buah syari'ah yang baik, dan syari'ah yang baik karena buah dari tauhid yang baik pula.

Adapun ruang lingkup akhlak dalam Islam ada tiga, yakni mencakup akhlak manusia dengan Allah Swt., akhlak manusia dengan sesama manusia, dan akhlak manusia dengan makhluk lain. Di antara tiga cakupan akhlak tersebut, maka akhlak dengan Allah Swt. merupakan akhlak yang paling pokok dan ukuran bagi yang lain. Akhlak dengan Allah mencakup segala ketaatan kepada-Nya, yakni taat menjalankan segala perintah-Nya dan meninggalkan segala laranga-Nya. Jika akhlak dengan Allah Swt. baik, pasti akhlak dengan sesama manusia dan dengan makhluk lainnya akan baik pula. Jika seseorang akhlaknya dengan orang lain dan dengan alam lingkungannya tidak

${ }^{16}$ Op.cit, ha. 144 
baik, maka akhlaknya dengan Allah Swt. sudah pasti belum baik. ${ }^{17}$ Adapun akhlak manusia kepada Allah Swt. antara lain ialah:

1) Beriman kepada Allah.”Maka itu berimanlah kepada Allah dan Rasul-rasulNya; dan jika kamu beriman dan bertakwa, maka bagimu pahala yang besar.'(QS Ali Imran [3]:179)

2) Beribadah kepada-Nya dan tidak menyekutukan-Nya. "Sembahlah Allah dan janganlah kamu mempersekutukan-Nya dengan sesuatu pun...'(QS. Al-Nisaa $\{4\}$ : 36)" Dan taatilah Allah dan Rasul, supaya kamu diberi rahmat."(QS Ali Imran [3]: 132)

3) Ikhlas. "Padahal mereka tidak disuruh kecuali supaya menyembah Allah dengan memurnikan ketaatan kepada-Nya dalam (menjalankan) agama yang lurus, dan supaya mereka mendirikan shalat dan menunaikan zakat; dan yang demikian itulah agama yang lurus.”(QS Al-Bayyinah [98]: 5)

4) Bersyukur atas segala karunia-Nya dan Qana'ah. "Hai orang-orang yang beriman, makanlah di antara rezeki yang baik-baik yang kami berikan kepadamu dan bersyukurlah kepada Allah, jika benar-benar kepada-Nya kamu menyembah.’'(QS Al-Baqarah [2]: 55)

5) Tadharru' "Berdoalah kepada Tuhanmu dengan berendah diri dan suara yang lembut. Sesungguhnya Allah tidak menyukai orang-orang yang melampaui batas."(QS Al-A'raaf [7]: 55)

6) Doa dan berharap hanya kepada Allah. "Dan janganlah kamu membuat kerusakan di muka bumi, sesudah (Allah) memperbaikinya dan berdoalah kepada-Nya dengan rasa takut (tidak akan diterima) dan harapan (akan dikabulkan). Sesungguhnya rahmat Allah amat dekat kepada orang-orang yang berbuat baik.'(QS Al-A'raaf [7]: 56)

7) Sabar dan tidak mengenal putus asa. "Dan berapa banyaknya Nabi yang berperang bersama-sama mereka sejumlah besar dari pengikut (nya) yang bertakwa. Mereka tidak menjadi lemah karena bencana yang menimpa mereka di jalan Allah, dan tidak lesu dan tidak (pula) menyerah (kepada musuh). Allah menyukai orang-orang yang sabar.”(QS. Ali Imran [3]: 146)

8) Menerima taqdir Allah.'Maka barang siapa yang tidak beriman kepada qadar baik dan qadar buruk, Allah pasti akan membakarnya dengan api neraka."(HR Ibnu Wahab).

9) Husnuzh-zhan."janganlah mati salah seorang dari kalian kecuali dalam keadaan bersangka baik kepada Allah."HR Muslim)

10) Tawakkal. "Maka apabila kamu telah membulatkan tekad, maka bertawakkallah kepada Allah. Sesungguhnya Allah menyukai orang-orang yang bertawakkal kepada-Nya."(QS Ali Imran [3]: 159

11) Malu kepada Allah.'Malu itu sebagian dari iman.'(HR Muslim)

12) Taubat dan istighfar. "Hai orang-orang yang beriman, bertaubatlah kepada Allah dengan taubatan nasuhaa (taubat yang semurni-murninya). Mudah-mudahan

17 Tim Dosen PAI Universitas Lampung, 2016 Pendidikan Agama Islam Berbasis Karakter di Perguruan

Tinggi (Jakarta: RajaGrafindo Persada), hal. 141 
Rabbmu akan menutupi kesalahan-kesalahanmu dan memasukkanmu ke dalam Jannah yang mengalir di bawahnya sungai-sungai."(QS At-Tahriim [66]: 8).

Adapun akhlak terhadap sesama manusia antara lain adalah sebagai berikut :

1) Akhlak terhadap diri sendiri. Menjaga kesucian diri, baik kesucian batin maupun lahir. Suci batin adalah bersih dari segala bentuk keyakinan yang musyrik, dari penyakit dengki, buruk sangka dan penyakit hati lain. Bersih lahir ialah suci dari hadas kecil dan besar. ".....di dalamnya masjid itu ada orang-orang yang ingin membersihkan diri dan sesungguhnya Allah menyukai orang-orang yang bersih." (QS Al-Taubah [9]: 108)

2) Memelihara kerapihan. Nabi Saw. Bersabda: "Sesungguhnya Allah itu indah dan menyukai keindahan.”(HR Muslim)

3) Berlaku tenang dan istiqamah."Dan hamba-hamba Tuhan yang Maha Penyanyang itu (ialah) orang-orang yang berjalan di atas bumi dengan rendah hati dan apabila orang-orang Jahil menyapa mereka, mereka mengucapkan kata-kata (yang mengandung) keselamatan. (QS Al Furqan [25] ayat 63). Dan pada ayat lain disebutkan "sesungguhnya orang-orang yang mengatakan: "Tuhan Kami ialah Allah" kemudian mereka meneguhkan pendirian mereka, Maka malaikat akan turun kepada mereka dengan mengatakan: "Janganlah kamu takut dan janganlah merasa sedih; dan gembirakanlah mereka dengan Jannah yang telaorangh dijanjikan Allah kepadamu". (QS Fushilat [41] ayat 30)

4) Disiplin, yakni pandai menggunakan waktu sebaik mungkin. "Demi masa. Sesungguhnya manusia itu benar-benar dalam kerugian, kecuali orang-orang yang beriman dan mengerjakan amal saleh dan nasehat menasehati supaya mentaati kebenaran dan nasehat menasehati supaya menetapi kesabaran (QS Al Ashr [103] ayat 1-3).

5) Selalu menambah pengetahuan"Allah akan meninggikan orang-orang yang beriman di antaramu dan orang-orang yang diberi ilmu pengetahuan beberapa derajat, dan Allah maha mengetahui apa yang kamu kerjakan. "(QS Al Mujadilah [58] ayat 1)

6) Tidak melemparkan dirinya kedalam kehancuran, seperti minum khomer, narkoba, dan lain-lain. “... dan janganlah kamu menjatuhkan dirimu sendiri ke dalam kebinasaan, dan berbuat baiklah, karena Sesungguhnya Allah menyukai orang-orang yang berbuar baik. "QS Al-Baqarah [2] ayat 195).

Adapun akhlak terhadap keluarga antara lain adalah sebagai berikut :

1) Berlaku baik kepada keluarga. “Orang mu'min yang paling sempurna imannya adalah yang terbaik akhlaknya. Dan sebaik-baik diantara kamu ialah yang paling baik kepada istrinya." (HR Turmuzi).

2) Menunaikan hak dan kewajiban dalam keluarga. "Seorang suami adalah bertanggung jawab kepada keluarganya, dia kelak akan dituntut atas tanggung 
jawabnya tersebut, seorang istri adalah bertanggung jawab di rumah suaminya, dia juga kelak akan dituntut atas tanggung jawabnya tersebut. '(HR Bukhari dan Muslim)

3) Mengasuh dan mendidik anak. "Kewajiban orang tua kepada anaknya ialah memberikan nama yang baik, mengajarkan menulis dan menikahkan apabila telah dewasa. "(HR Ibnu Najjar)

4) Berbakti kepada kedua orang tua. "Dan Tuhanmu telah memerintahkan supaya kamu jangan menyembah selain Dia dan hendaklah kamu berbuat baik pada ibu bapakmu dengan sebaik-baiknya. Jika salah seorang diantaranya atau kedua-duanya sampai berumur lanjut dalam pemeliharaanmu, Maka sekali-sekali janganlah kamu mengatakan kepada keduanya perkataan "ah" dan janganlah kamu membentak mereka dan ucapkanlah kepada mereka perkataan yang mulia. "(QS.Al-Israa [17] ayat 23). Mengucapkan kata "Ah" kepada orangtua tidak dibolehkan oleh agama apalagi mengucapkan kata-kata atau memperlakukan mereka dengan lebih kasar daripada itu. Rasulullah SAW bersabda: "Semua dosa dilambatkan Allah membalasnya menurut apa yang dikehendaki-Nya sampai hari kiamat, kecuali kedurhakaan kepada orangtua, maka sesungguhnya Allah mempercepat pembalasannya di waktu dia masih hidup sebelum mati." (HR Thabrani)

5) Membangun silaturahin, baik kepada keluarga, tetangga maupun kepada masyarakat luas. Firman Allah “... dan bertakwalah kepada Allah yang dengan (mempergunakan) nama Nya kamu saling meminta satu sama lain, dan peliharalah hubungan silaturahim. Sesungguhnya Allah selalu menjaga dan mengawasi kamu." (QS Al-Nisaa [4]:1)

Adapun akhlak terhadap tetangga dan masyarakat luas antara lain adalah sebagai berikut:

1) Berlaku baik terhadap tetangga. "Barangsiapa yang mengaku beriman kepada Allah dan hari akhir, maka berbuat baiklah kepada tetangganya." (HR Bukhari dan Muslim)

2) Memberikan apa yang menjadi hak tetangga. Sabda Nabi Saw: "'Hak tetangga yaitu: (1) Kalau ia ingin meminjam, hendaklah engkau pinjami. (2) Kalau ia minta tolong hendaklah engkau tolong. (3) Kalau ia sakit hendaklah engkau jenguk dia. (4) Kalau ia ada keperluan, hendaklah engkau beri kepadanya. (5) Kalau ia jatuh miskin, hendaklah engkau beri bantuan kepadanya. (6) Kalau ia mendapat kesenangan, hendaklah engkau ucapkan selamat kepadanya. (7) Kalau ia ditimpa kesusahan, hendaklah engkau hibur dia. (8) Kalau ia meninggal dunia, hendaklah engkau antarkan jenazahnya. (9) Jangan engkau membangun rumah lebih tinggi dari rumahnya kecuali engkau meminta izin kepadanya, karena hal itu menghalangi ia dari angina. (10) Jangan engkau ganggu ia dengan bau masakanmu kecuali engkau beri masakan itu. (11) Jika engkau membeli buah-buahan hendaklah engkau hadiahkan juga kepadanya, dan kalua engkau tidak memberi, 
bawalah masuk kedalam rumahmu secara sembunyi-sembunyi. (12) Dan jangan sampai anakmu keluar membawa buah-buahan itu, karena nanti anak(tetangga)nya sedih karena menginginkan buah itu."(HR Abu Syaikh).

3) Memberi hadiah. Nabi Saw. bersabda: "Jika engkau memasak gulai, maka banyakkanlah kuahnya serta perhatikanlah tetanggamu, kemudian hadiahkanlah sebagian daripadanya kepada tetanggamu, dengan cara yang baik." (HR Muslim).

4) Berbuat baik kepada semua orang. "Sembahlah Allah dan janganlah kamu mempersekutukan-Nya dengan sesuatupun., Dan berbuat baiklah kepada ibubapak, karib kerabat, anak-anak yatim, orang-orang miskin, tetangga yang dekat dan tetangga yang jauh, dan teman sejawat, Ibnu sabil dan hamba sahayamu. Sesungguhnya Allah tidak menyukai orang-orang yang sombong dan membanggabanggakan diri,",(QS Al-Nisaa [4]: 36)

5) Menghormati guru. Sabda Nabi Saw. :"Muliakanlah 'ulama, karena mereka adalah pewaris para nabi; maka barang siapa memuliakan mereka, sesungguhnya mereka telah memuliakan Allah dan Rasul-Nya."(HR Thabrani).

Pendidikan moral di sekolah dilakukan oleh guru dengan tujuan untuk membentuk peserta didik memiliki karakter yang baik, berakhlak mulia, agar kelak berguna bagi bangsa dan negara. Pendidikan tidak dikesankan sebatas penyampaian doktrin-doktrin agama tentang halal-haram, tata cara ibadah berikut pahala - surga dan ancaman dosa neraka, tetapi harus banyak berbicara dimensi pemaknaan yang mengajak anak didik meraih kesadaran terhadap nilai. Unsur-unsur ajaran agama menyangkut ibadah dan hokum-hukum agama tentu saja harus disampaikan, tetapi tidak boleh dilupakan bahwa tujuan utama pendidikan agama Islam adalah internalisasi nilai sehingga menjadi karater.

Pengajaran moral melalui pembahasan yang divergen atas nilai-nilai yang terkandung dalam materi ajar melalui kegiatan-kegiatan sederhana, tetapi mengena akan mengefektifkan pembentukan karakter moral pada anak didik. Pada gilirannya akan membentengi akhlak anak didik dari perbuatan yang dilarang (amoral). Hal ini sangat penting bagi fondasi pembangunan bangsa di masa depan. Ketika karakter moral teah membudaya, ia akan menjadi etos kerja bangsa sehingga proses-proses politik, perumusan kebijakan, dan praktik pemerintahan dan pembangunan akan dilandasi moralitas yang kuat, terhindar dari berbagai penyimpangan.

Karakter atau watak seseorang dapat dibentuk, dapat dikembangkan dengan pendidikan nilai. Pendidikan nilai akan membawa pada pengetahuan nilai, pengetahuan nilai akan membawa pada proses internalisasi nilai, dan proses internalisasi nilai akan mendorong seseorang untuk mewujudkannya dalam tingkah laku, dan akhirnya pengulangan tingkah laku yang sama akan menghasilkan watak atau karakter seseorang.

Pendidikan agama Islam bagi anak didik dirasakan sangat penting dalam membentuk dan mengembangkan karakter siswa. Pendidikan agama dan moral harus saling berintegrasi dan berinteraksi melalui realitas sosial yang berkembang di masyarakat. Pendidikan diyakini orang sebagai proses pembentukan pribadi manusia semenjak kecil sampai tua yang mengandung keyakinan bahwa Pendidikan menjadi 
proses yang tidak pernah selesai. Sebab dalam kenyataannya, Pendidikan yang memuat nilai-nilai keagamaan pada akhirnya mampu membentuk manusia seutuhnya.

\section{KESIMPULAN}

Pendidikan agama Islam bagi anak didik dirasakan sangat penting dalam membentuk dan mengembangkan karakter siswa. Pendidikan Islam adalah suatu usaha untuk mengarahkan manusia menjadi bermanfaat, beradab dan bermartabat dalam menjalankan kehidupan sesuai dengan ajaran Islam, serta menghasilkan output yang berkarakter baik.

Menanamkan pendidikan Islam pada anak sejak dini berarti ikut mempersiapkan generasi bangsa yang berkarakter, anak-anak adalah calon generasi bangsa yang diharapkan mampu memimpin bangsa dan menjadikan negara yang berperadaban, menjunjung tinggi nilai-nilai luhur bangsa dengan berakhlak mulia serta menjadi generasi yang berilmu pengetahuan dan bertakwa kepada Tuhan Yang Maha Esa.. Oleh karena itu pembelajaran pendidikan agama Islam di sekolah sebagai salah satu upaya pembentukan karakter siswa sangatlah penting. Pembentukan karakter anak akan lebih baik jika muncul dari kesadaran keberagamaan bukan hanya karena sekedar berdasarkan prilaku yang membudaya dalam masyarakat

\section{DAFTAR PUSTAKA}

Adisusilo, J.R, Sutarjo, 2014, Pembelajaran Nilai Karakter, Jakarta, PT RajaGrafindo Persada

Arifin, H.M, 2014, Ilmu Pendidikan Islam, Jakarta, Bumi Aksara

Daud Ali, Muhammad, 2016, Pendidikan Agama Islam, Jakarta, RajaGrafindo Persada

Makbuloh, Deden, 2015, Pendidikan Agama Islam, Jakarta, PT RajaGrafindo Persada

Putra Daulay H., 2014, Pendidikan Islam dalam Perspektif Filsafat, Jakarta, Kencana

Shafwan, Muhammad Hambal, 2014, Intisari Sejarah Pendidikan Islam, Solo, Pustaka Arafah

Shaleh, Abdul Rachman, 2005, Pendidikan Agama \& Membangun Watak Bangsa, Jakarta,

\section{RajaGrafindo Persada}

Tim Dosen Pendidikan Agama Islam Universitas Lampung, 2016, Pendidikan Agama Islam 
Berbasis Karakter Di Perguruan Tinggi, Jakarta, RajaGrafindo Persada

Yaumi, Muhammad, 2014, Pendidikan Karakter Landasan Pilar \& Implementasi, Jakarta,

Prenada Media Group 